\title{
The distribution of ghrelin cells in the human and animal gastrointestinal tract: a review of the evidence
}

\author{
K.M. Mehdar \\ Najran University, East of Airport, Najran, Saudi Arabia \\ [Received: 2 April 2020; Accepted: 1 July 2020]
}

The growth hormone and appetite are regulated by a 28-peptide hormone called ghrelin, which is produced in the stomach, pituitary gland, and other body tissues. The physiological roles fulfilled by ghrelin include regulation of food intake, cardiac output, reproductive system, proliferation of cells, and formation of osteoblasts, as well as action against inflammation/fibrosis. The ghrelin present in the body can be distinguished as acylated ghrelin and deacylated ghrelin. Furthermore, both in humans and other animals, the entirety of the gastrointestinal tract comprises ghrelin cells, which are classified as open-type and closed-type cells. The present study reviews the evidence about how ghrelin cells are distributed in the human and the animal body. (Folia Morphol 2021; 80, 2: 225-236)

Key words: ghrelin, mucous membrane, stomach, gastrointestinal tract, gastric

\section{OVERVIEW}

The discovery of ghrelin as an endogenous ligand for the growth hormone secretagogue receptor (GHS-R) in the stomach was made in 1999. Since then, ghrelin has been found to be involved in growth hormone (GH) secretion, dietary intake, glucose metabolism, memory, and effects against depression $[50,79,86]$.

Ghrelin is mainly produced in the upper part of the stomach, which is called the fundus. Ghrelin remains available in a proportion of $35-45 \%$ following a complete gastrectomy $[4,30,73]$. Its action on the body is related to its close association with the GH secretagogue subtype 1a (GHS-R1a), a G protein-coupled receptor [13]. A large number of tissues and organs, including the peripheral and central nervous systems, have high expression of both ghrelin and GHS-R1a. Thus, additional organs support ghrelin production, even though the stomach is the primary producer. Among the organs that have been found to have ghrelin gene expression in both humans and rodents at various developmental stages are the intestine [32], brain [89], heart [57], lung [21], testis [27], immune cells [17], and pancreas [105].

Research has uncovered that ghrelin and GHS-R1a fulfil key bioactions in a wide range of physiological processes, including regulation and homeostasis of central food intake [66], modulation of the cardiovascular system [111], gastric acid production and circulation improvement [56], as well as regulation of cell proliferation and survival [74].

Ghrelin cells have maximum prevalence in the gastric body mucosa, but this prevalence decreases in the gastric antrum and in the small intestine, especially in rodents. In adult bodies, ghrelin is produced chiefly by the stomach, so other sources have not been closely investigated. For instance, studies on rodents have not considered other sources of ghrelin production, choosing to focus on the stomach fundus. However, it 
has been reported that $20 \%$ of circulating ghrelin was still available in rodents following fundectomy [105].

\section{GHRELIN HISTORY AND CHARACTERISTICS}

The discovery of peptide derivatives mediating GH secretion from the anterior pituitary was made by Cyril Bowers and Frank Momany towards the end of the 1970s [8, 62]. The formation of the discovered growth hormone-released peptides (GHRPs) was found to be based on chemical alteration of met-enkephalin, including GHRP-6 and GHRP-2 [85]. In a 1996 study, GHS and GHRP were used as agonists by Roy Smith and Lex van der Ploeg to assess the GHS candidate MK0677 for the GHS-R1a clone [44]. This sparked methodical investigations with the purpose of categorising the endogenous GHS-R1 ligand. It was only with the discovery of the GHS-R1 cognate agonist in 1999 that the ligand became effective. The name "ghrelin" was given to the hormone consisting of 28 peptides that was isolated from rodent gastric extracts [49]. In 2000 , it was found that ghrelin was responsible for regulation of weight and intake of fat and glucose by acting on the cerebral tissue [97].

Derived from the root "ghre" of proto-Indo-European origin, the term "ghrelin" reflects its function as a GH peptide. Interestingly, "ghre" and "lin" are widely accepted in hormone terminology $[9,65]$.

\section{THE PROCESS OF GHRELIN DEVELOPMENT}

To reach full development, ghrelin goes through a number of post-transitional modifications. It undergoes translation as preproghrelin, a precursor protein with 117 amino acids. This is followed by cleavage of the $\mathrm{N}$-terminal signal co-translation to generate 94 amino acids and transfer to the endoplasmic reticulum lumen proghrelin comprising 23 amino acids and 66AA carboxyterminal peptide known as C-ghrelin (Fig. 1). By binding to fatty acyl group (o-ctanoyl), proghrelin undergoes octanoylation to serine residue (Ser3), which is the third amino acid related to the enzyme known as ghrelin O-acyltransferase (GOAT). A ghrelin acylation enzyme, GOAT, serves to highlight how important acyl modelling is for ghrelin physiology. Switch is of particular significance in octanoylation and, to a lesser extent, to the ghrelin effect on systemic metabolism. Clear evidence regarding the central function of GOAT in activating ghrelin has been brought forth $[37,109]$. The formation of mature ghrelin results from packaging proghrelin into secretory vesicles and alteration by protein convertase enzymes. Consisting of 28 amino acids, mature ghrelin is released into the circulation [34]. Conversely, if proghrelin is cleaved at the C-terminal (C-ghrelin), it can yield obestatin with 23 amino acids and opposite role to ghrelin [71].

The stomach-derived human ghrelin gene is present on the third chromosome (3p25-26) and consists of five exons and four introns. It secretes various bioactive molecules, including two types of ghrelin, namely, acylated ghrelin (AG) and deacylated ghrelin (DAG), as illustrated in Figure 1 [56]. In mammalian bodies, the stomach is the producer of AG [7].

In the human body, AG, DAG, and C-ghrelin are the forms of ghrelin found in the bloodstream [42, $70,71]$. GOAT undertakes acylation of the AG peptide, with expression restricted chiefly to the gut, stomach, and pancreas. Hydrolysis causes the loss of the $\mathrm{N}$-acyl group from DAG [37]. Meanwhile, C-ghrelin comprises the entire obestatin coding area and may undergo cleavage for secretion of peptides, including obestatin [71].

In general, AG in the bloodstream is less than $10 \%$, while DAG and C-ghrelin in the human bloodstream account for over $90 \%$ of the total ghrelin in the bloodstream [81].

When the gastric mucosa is surgically extracted, there is a reduction of around $80 \%$ in the synthesis of C-ghrelin in rats $[20,53]$ and in humans [4]. Understanding is yet to be achieved as to whether the same or similar secretory pathways release ghrelin and DAG into the circulation. In rats, gastric ghrelin is broken down via deacylation and $\mathrm{N}$-terminal proteolysis [22], with deacylation being undertaken by lysophospholipase I [84]. In rats, receptor activity is not exhibited by DAG against GHS-R1a, GH release or other endocrine events. Another compound demonstrating bioaction is unesterified GHRL, the activity of which is underpinned by a GHS-R other than GHS-R1a [7, 82].

\section{MORPHOLOGICAL CHARACTERISATION OF GHRELIN CELLS IN THE GASTROINTESTINAL TRACT}

In earlier studies, gastric ghrelin was characterised as deriving from an ultra-structured, "hormonal-less" A-like cell present in rat pancreas and human P/D1 cells. In the rodent gastrointestinal tract (GIT), oxyntic mucosa has the greatest prevalence of ghrelin cells, followed by the gastric antrum and small intestine $[18,19,75]$. 


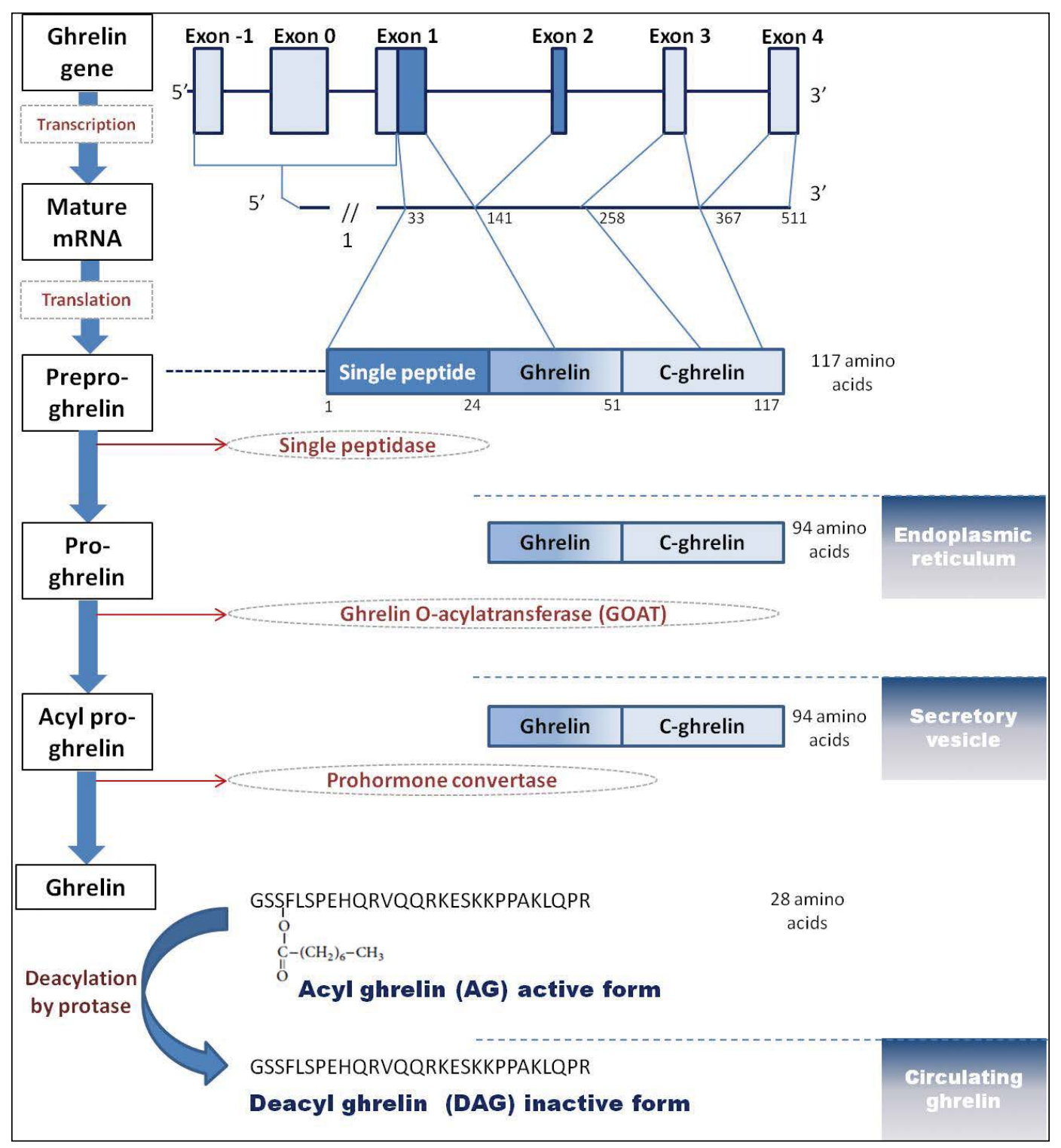

Figure 1. Schematic representation of the process of ghrelin maturation, starting with the structure of the human ghrelin gene to its active peptide.

In adult individuals, ghrelin is primarily produced by the stomach, so the other hormone sources have been studied to a lesser extent. The stomach fundus has been particularly extensively explored in studies on rodents. The ghrelin in the rodent bloodstream post-fundectomy has been reported to be at a level of $20 \%$ [19], reflecting the fact that there are other sources of the hormone besides the stomach, such as the pancreas and intestines [105]. The presence of ghrelin-containing $X$ cells in rodent stomach has been indicated through immunohistochemistry, immunoelectron-based microscopy, and hybridisation [75, 78].

In rodents, ghrelin cells have been found throughout the GIT apart from the myenteric plexus, with the stomach body and upper part displaying the greatest production of ghrelin cells. Meanwhile, in the large and small intestines, ghrelin cells are found in the epithelium of crypts and villi, but these cells are less dense in the large intestine $[41,45]$.

Most ghrelin entero-endocrine cells are classified as closed-type cells because they are not continuous to the gastrointestinal lumen. By contrast, ghrelin cells continuous to the gastrointestinal lumen are classified as open-type cells and are most prevalent in the stomach [94].

In terms of histology, there are clear differences between the ghrelin cells in the stomach and those in the intestinal tract. The stomach contains spherical cells of small size known as closed-type cells $[19,77$, 112], while the small intestine and colon contain both 


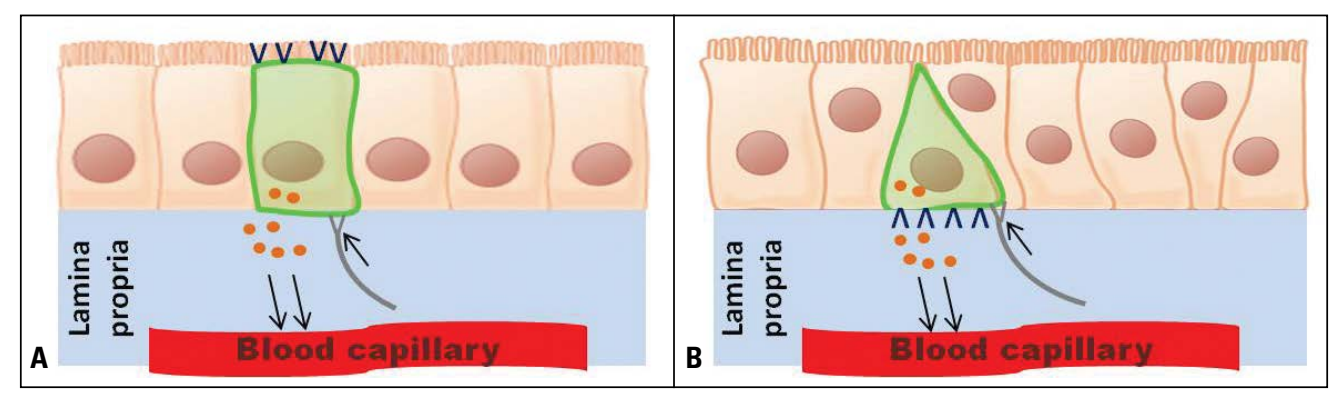

Figure 2. Schematic illustration of the two types of ghrelin cells; $\mathbf{A}$. Closed-type ghrelin cells delineated in green colour; on the superior part, the cells are sealed by epithelial cells so there is no direct interaction with the lumen; when neurons are stimulated, ghrelin is released, as indicated by the grey colour, and the cell basal area gives rise to nutrient receptors, as indicated by the blue colour; B. Open-type ghrelin cells delineated in green colour; these cells communicate directly with the lumen on their superior part, while the inferior part gives rise to nutrient receptors, shown in blue colour. The small orange dots in both types of cells indicate the spread of ghrelin to lamina propria, from which it permeates the gastric capillaries and finally the systemic circulation.

Table 1. The distribution of ghrelin cells in humans and other animals, listed alphabetically

\begin{tabular}{lccc}
\hline & Site of ghrelin cells & Morphology of the ghrelin cells & References \\
\hline Amphibians and reptiles & Stomach (mucosal layer) not in myenteric plexuses and muscle layer & Closed cell type & {$[1,11]$} \\
Canine & Stomach & Closed and open types & {$[75]$} \\
Chicken & First part of the stomach (middle layer of mucosal layer) & Closed cell type & {$[98]$} \\
$\begin{array}{l}\text { Dog } \\
\text { Human }\end{array}$ & Stomach & Closed and open types & {$[75]$} \\
Mice & Stomach (all parts of the fundic gland) & Open and closed cell types & {$[26]$} \\
Pigs & Gastric fundus & Closed and open types & {$[102]$} \\
Rainbow trout & From stomach to cecum & Closed and open types & {$[100]$} \\
Rats & Stomach (mucosal layer) & Closed and open types & {$[79]$} \\
\hline
\end{tabular}

closed-type cells with a pyramidal or expanded shape and open-type lumen cells that have more than one cytoplasmic process and are located in the apical cell membrane (Fig. 2).

The regulation of the open-type cells is mechanical, based on luminous signals (e.g. pH, nutrients), while the regulation of the closed-type cells is based either on mechanical effect or the effect of additional hormones released into the circulation from the GIT (e.g. leptin, somatostatin, glucagon) $[38,100]$. One study on rainbow trout discovered that the distribution of ghrelin cells in the stomach mucosa encompassed both closed-type and open-type cells [76]. Furthermore, research employing electron microscopy has revealed that spherical and dense granules of gastric mucosal cells exhibited the ghrelin immunogold mark $[75,95,110]$. Ghrelin cells have somewhat small and round secretory granules, with varying electron density in their cores, from solid to rather electron-lucent. Consequently, the limiting membrane adheres closely to the dense core in the majority of granules.
In the foetus, there is no difficulty differentiating ghrelin cells from $\beta$ cells based on the thick uneven structure of their granules [105]. Meanwhile, on a study on rodents, hamsters were shown to have significantly smaller ghrelin granule diameters (200.8 \pm $\pm 8.8 \mathrm{~nm})$ compared to mice $(277.7 \pm 11.1 \mathrm{~nm})$ and rats $(268.8 \pm 13.0 \mathrm{~nm})$ [55]. There were no major differences in ghrelin-immunoreactive cells between mice and humans (147 $\pm 30 \mathrm{~nm})$; however, by comparison to rats and humans, dogs displayed considerably larger ghrelin cell granules (183 $\pm 37 \mathrm{~nm}$ vs. $273 \pm 49 \mathrm{~nm}$ ). Ultrastructure studies have characterised ghrelin cells as well-defined spherical, compact-to-thin, haloed secretory cells around $140 \mathrm{~nm}$ in width, located in the core of the oxyntic gland, and presenting X/A-like granules. In the stomach, ghrelin cells can be found in the proximity of cells that secrete histamine. In dogs, ghrelin cells are typically spherical and associated with a range of sizable, solid, electron-dense X-like granules of oval shape with significant marking for ghrelin antibodies [26]. 
Positive ghrelin cells are likely to be assimilated in the plasma instead of the intestinal tract because they are found close to capillaries and do not have contact with the oxyntic gland lumen [9]. Table 1 provides an overview of the GIT location of cells that secrete ghrelin.

\section{GHRELIN CELL DISTRIBUTION IN HUMANS AND ANIMALS}

Distribution of ghrelin cells in the human GIT

Gastrectomy is an intervention performed in cases of cancer or perforated ulcer, involving removal of the stomach, either partially or entirely. One study concluded that the stomach was the main source of ghrelin in the bloodstream since patients who had undergone complete gastrectomy exhibited a $65 \%$ reduction in plasma-like immune rates [4]. Similarly, a different study reported that the levels of immunoreactive ghrelin in plasma were almost halved in the aftermath of complete gastrectomy compared to pre-gastrectomy; however, there was a subsequent progressive rise in the plasma ghrelin levels, suggesting that other sources of ghrelin offset the ghrelin lost through stomach removal [87].

A sex-based difference in the distribution of ghrelin cells and levels of ghrelin in plasma has been discovered, with the plasma ghrelin levels being higher in females than in males [58].

It has also been proposed that, in humans, the levels of ghrelin in the bloodstream were regulated by sex hormones, since testosterone therapy was observed to enhance ghrelin levels in hypogonadal patients [52]. The regulatory effect of sex hormones was reinforced by the observation that there was a higher number of ghrelin cells with expression of the oestrogen $\alpha$-receptor 3 days post-ovariectomy [36].

Anti-ghrelin antibody was employed by Tanaka-Shintani and Watanabe [93] to analyse how immunoreactive ghrelin cells were distributed in the gastric mucosa in humans, with results revealing that those cells were mainly located in the stomach fundus and there was a close correlation between their distribution and the distribution of parietal cells. The overall cell number for rich and mild types was $3.70 \pm 3.31$ and $1.18 \pm 2.67$, respectively, for every area of the fundus. The area of the duodenum also contained immunoreactive ghrelin cells, although not in such a great abundance as the stomach [108].

Other studies reported that the intestine had the greatest concentration of immunoreactive ghrelin cells, with lower concentrations in the duodenum, jejunum, and ileum, and absence in the colon. The majority of the ghrelin cells were present in the Lieberkühn crypts [61, 94].

Obese females have been observed to have a greater abundance of ghrelin cells than obese males $(p>0.05)$. The stomach body had the greatest concentration of ghrelin cells, followed by the fundus and antrum. By contrast, patients with $\mathrm{H}$. pylori infection or gastritis were found to have a lower abundance of ghrelin cells [114].

A study that investigated how the levels of ghrelin in serum, the number of ghrelin cells, and weight were correlated in patients with Prader-Willi syndrome reported that the stomach fundus contained a number of ghrelin cells that was 2-3 times higher, while the levels of ghrelin in plasma were also abnormally high, even in younger patients [93].

In the context of embryonic development, ghrelin cells appear in the foetal stomach from day 18 , proliferating in direct proportion with foetal growth. During the first week of embryonic development, positive-immunostained ghrelin cells emerged at the base of the gland, while in the third week, they emerged at the base and neck, achieving distribution from the base to the neck of the fundic gland during post-neonatal development [80]. In a different study, the number of immunoreactive ghrelin cells was low at day 21 of embryonic development, but grew progressively afterwards and then declined [43]. Furthermore, it has been suggested that the increase in the levels of gastric ghrelin mRNA by age was correlated with the rise in the number of ghrelin cells [69].

In humans, another organ associated with the presence of immunoreactive ghrelin cells is the pancreas. The cells secreting $\alpha$ glucagon and $\beta$ insulin and the $\delta$ cells in pancreatic islets have endogenous expression of ghrelin, whilst the pancreatic $\alpha$ and $\beta$ cells have preponderant expression of GSH-R1a $[60,99]$. Furthermore, it has been discovered that, by comparison to the adult pancreas, the foetal and neonatal pancreas has a higher number of ghrelin cells.

Evidence has been produced regarding the consistent lack of hormone related to immunoreactive ghrelin cells in the common islet-type of cells, namely, $\alpha, \beta, \delta$, and pancreatic polypeptide cells (PP-cells) based on double or triple immunostaining for ghrelin and four major islet hormones (i.e. glucagon, insulin, somatostatin, and PP-cells) [40]. Ghrelin cells have also been found in foetal and neonatal rat pancreas 
$[25,101]$ and in mouse pancreas [16]. Furthermore, from day 8 of mouse embryonic development, ghrelin cells start to participate in the formation of Langerhans islets. The pancreas secretes ghrelin on a constant basis during embryonic development, but the release rate decreases rapidly after birth. In humans, only a particular group of cells has ghrelin expression in islets; by contrast, in mice, a subset of $\varepsilon$-cells is chiefly responsible for the glucagon-based production of ghrelin in islets.

The insulin produced by the pancreatic $\beta$ cells undertakes modulation of glucose homeostasis. The involvement of ghrelin in glucose homeostasis has been highlighted by a number of studies and it is presumed that, in humans, ghrelin has an effect on how this process is modulated [18].

Ghrelin and GHS-R1 a may have a stimulating effect on the functions of the pancreas, as the receptor has been found to be present in islands. Furthermore, there is evidence that ghrelin and insulin have a reciprocal effect on the modulation of their production [18].

\section{Distribution of ghrelin cells in rat GIT}

In one study, anti-acylated rat ghrelin antiserum was employed to histologically characterise rat ghrelin cells and determine how they were distributed. It was observed that the distribution of ghrelin cells spanned the whole rat gastrointestinal mucosa, from the stomach to the colon. Moreover, both closed-type and open-type of cells were distinguished, as well as both types of ghrelin, with DAG being present mainly in the perinucleus region and $A G$ occurring at the edges of the cytoplasm [77].

Morphometric analysis revealed that the greatest concentration of ghrelin cells was in the rat stomach, followed by the duodenum, with reduced concentration in the large and small intestines [68]. Sex-based differences ghrelin cell presence in rats have also been reported, with female rats displaying a higher number of ghrelin cells and from an earlier developmental stage [59].

In Teive et al. [94], Wistar rats were employed to determine whether it was possible to offset the ghrelin lost due to gastrectomy by increasing the presence of ghrelin cells in the duodenum. To that end, the rats were subjected to sleeve gastrectomy followed by reoperation 30-60 days later. The latter, involved dissection of a duodenal segment for the purposes of immunohistochemistry to determine the number of ghrelin cells. Results indicated a proliferation of immu- nopositive ghrelin cells in the duodenum, which was considered to be unrelated to the sleeve gastrectomy.

In Sun et al. [90], a gradual rise in the levels of mRNA gastric ghrelin was observed during the second and third weeks post-partum. Similarly, in Sun et al. [92], the levels of gastric ghrelin increased constantly up to 3 months post-partum. Another study reported that the gastric and intestinal tract contained both open- and closed-type of ghrelin cells, with the stomach having the greatest concentration of ghrelin cells, while the number of open-type cells increased steadily from the stomach to the lower intestine. In addition, rats of both sexes exhibited positive ghrelin cells in the stomach immediately post-partum, with a steady rise in the level of expression of gastric ghrelin up to two months of age after birth [68].

In Wortley et al. [106], the use of immunohistochemistry and immunoelectron microscopy to investigate ghrelin cell distribution in the stomach of Wistar rats revealed that immunoreactive positive ghrelin cells spanned the area from the fundic gland neck region to the actual fundus glands. Furthermore, the granules of enteroendocrine type $X$ cells were discovered via ultrastructural analysis to have positive-immunolabelled ghrelin cells.

Immunohistochemistry was also the approach adopted in McFarlane et al. [59] to identify ghrelin-positive mast cells and establish where they were found and how they were distributed. Results showed that ghrelin was produced by the mast cell granules, which were smaller than tryptase-positive mast cells. Thus, it was confirmed that mast cell granules present in rodent stomach wall contained ghrelin, implying that mast cells were an important ghrelin source.

\section{Distribution of ghrelin cells in mouse GIT}

The preferred animal model for developmental studies on gene modulation is the mouse. From the fact that appetite is stimulated by ghrelin in both rodents and humans, it has been deduced that the hormone represents an orexigenic antipode to anorexigenic leptin, anticipating that appetite suppression and weight loss could be achieved through pharmacologic ghrelin activation [91, 102]. However, this theory has not been supported by investigations of ghrelin on mouse models, which did not exhibit significant appetite suppression or weight loss $[55,109$, $113,115]$. On the other hand, it has been observed that mice with ghrelin deficiency do not have an abnormal body weight or dietary intake, and actually, 
it appears that, in mice, ghrelin serves primarily to regulate glucose in the blood. Several studies have reported that tolerance to glucose is enhanced by ghrelin ablation by stimulating elevated production of insulin $[48,107]$. Similar to mice with ghrelin deficiency, mice with GHS-R deficiency do not gain weight when given a diet rich in fat. Some studies have argued that, to some extent, this might be due to the fact that such mice have a moderate pituitary and use fat selectively for energy purposes $[39,47]$. In Churm et al. [12], it was found that mice with ghrelin deficiency and of different origins displayed reduced body weight and fat mass, which was tentatively attributed to intensified energy use and movement. Furthermore, studies on mouse models with ghrelin knockout concluded that dietary intake or development did not depend critically on the ghrelin peptide [113], and mice with ghrelin knockout did not eat less or were of smaller size, but they did differ from wild counterparts in terms of their behavioural phenotype related to dietary intake $[102,113]$.

\section{Ghrelin cell distribution in non-mammalian vertebrates}

A number of vertebrates have been identified to have ghrelin cells $[29,54]$, with evolutionary highly conserved ghrelin $\mathrm{N}$-terminal areas. One study has been successful in isolating ghrelin from trout, revealing that octanoic or decanoic acid modified the third residue of ghrelin serine [23]. A different study has detected immunopositive ghrelin cells throughout the GIT, but with a gradual reduction in number from the stomach to the duodenum, ileum, cecum, and colon [114].

In Wortley et al. [106], hamsters were used to show that the ghrelin cells were the same as the $X$ cells of proper gastric glands and those cells were fewer than in rats and mice. Meanwhile, in Steinert et al. [88], similarities were reported between ghrelin cells in mammals or birds and ghrelin cells in amphibians and reptiles; ghrelin cells were present on the stomach mucosal layer but absent on the mesenteric nerve plexus or stomach muscularis externa.

In birds, immunopositive ghrelin cells have been detected in the proventriculus mucous layer, which is the first area of the stomach fundic gland, where digestion enzymes act on the food intake alongside the gizzard. On the other hand, immunoreactive ghrelin cells have been found to be absent from the avian mesenteric plexus; compared to the mucosal layer, a higher number of immunopositive cells has been identified in the middle layer and the majority of ghrelin cells were closed-type cells [72].

In Tschop et al. [96], the nutraceutical properties of a diet of Spirulina (Arthrospira platensis) were investigated by analysing the expression of oligopeptide transporter 1 (PepT1) and ghrelin in the GIT of zebrafish (Danio rerio). After 2 days of fasting, ghrelin began to be secreted and its levels increased after 5 days, initially in the stomach and then in the rest of the GIT. It was thus concluded that, in the context of fasting and feeding, the effect of ghrelin on zebrafish was opposite that of PepT1 [96].

\section{THE ROLE OF GHRELIN AND RELATED RECEPTOR}

A number of physiological processes unfold with the involvement of ghrelin. An overview of the key roles performed by ghrelin is provided in Figure 3 .

Belonging to the superfamily of G-protein coupled receptors, the ghrelin receptor, GHS-R, has seven transmission domains across the helix. In humans, the GHS-R gene is made up of two exons and one intron and is located on chromosome 3 (3q26.2) [13]. GHS-R is differentiated into GHS-R1A, which is a 366 AA protein with seven transmembrane helix domains, and GHS-R1B, which is a 289 AA protein with five transmembrane helix domain [15].

In mammals, among the behaviours of greatest complexity is food intake, which is controlled by different homeostatic and external factors. A key hormone for food intake regulation is ghrelin $[2,10]$. In rodents, ghrelin circulation intensifies during feeding before reverting to normal levels once fullness is achieved $[2,5]$. Weight gain often accompanies chronic therapies owing to increase in adiposity [24]. In humans, food intake has been observed to increase when peripheral ghrelin was administered. There is also a regular increase and reduction in the levels of ghrelin in the human bloodstream, corresponding to the daily intervals of food consumptions [83].

Research using mouse models has reported that angiogenesis was consistently promoted when ghrelin was administered. According to a recently conducted study on rat model of cardiopulmonary bypass, cardiopulmonary bypass-related inflammatory response, apoptosis, and oxidative stress were reduced when ghrelin was administered, while the heart pumping function was maintained based on signalling GHS-R1a and Akt [14]. 


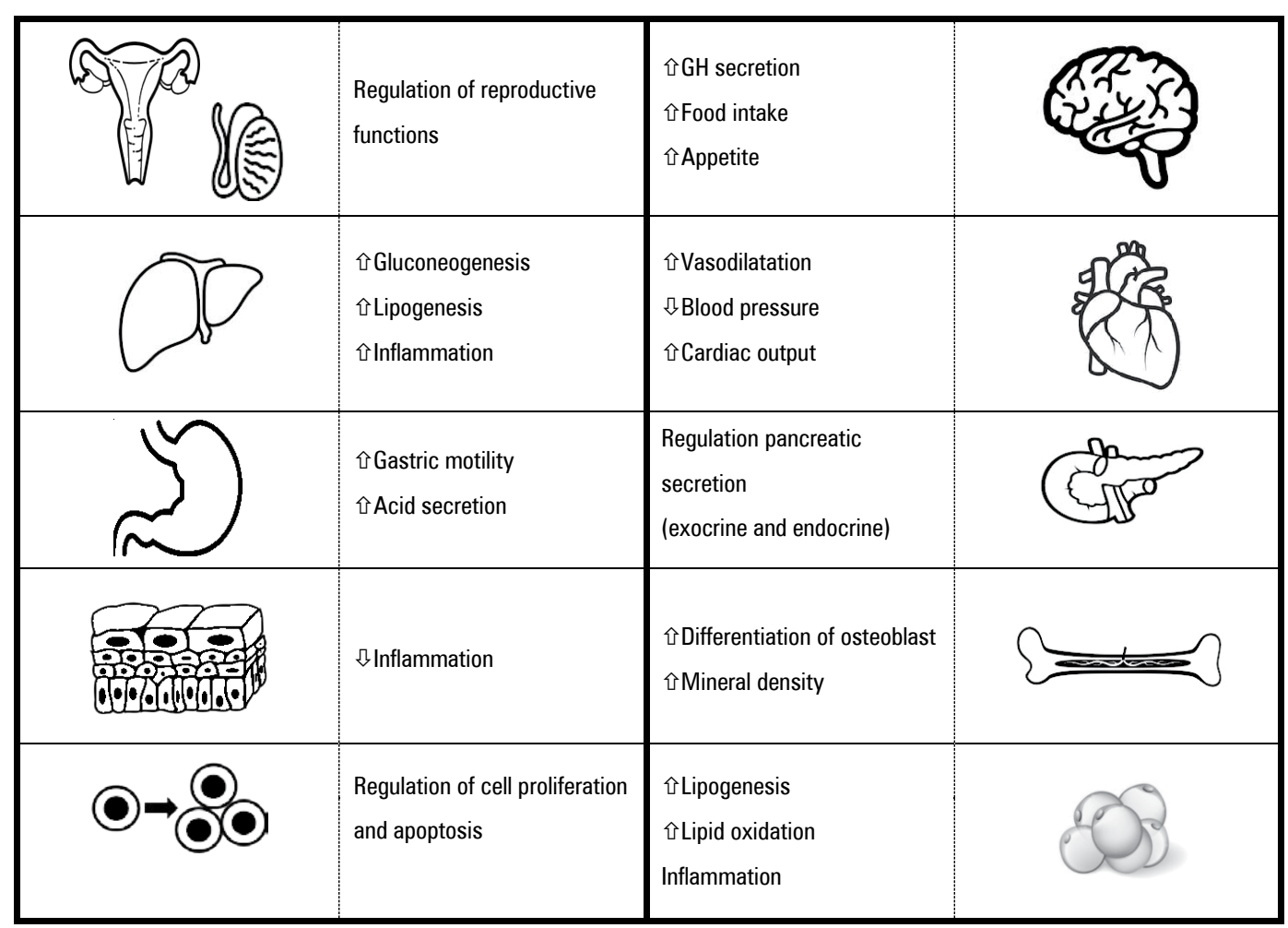

Figure 3. The key roles fulfilled by ghrelin in physiological processes; $\mathrm{GH}$ - growth hormone.

Studies on rats have also found that ghrelin and its receptor were associated with osteoblast development, with ghrelin being reported to help osteoblasts proliferate and differentiate both in vitro and in vivo [56]. The regulatory effect of ghrelin on bone development seems to be underpinned by ghrelin induction of the phosphorylation of adenosine monophosphate active protein kinase [46]. Despite promoting the growth of human osteoblasts, which show exclusive expression of GHS-R1b isoform inactive receptor, it appears that ghrelin has no effect on the differentiation of osteoclasts in rats [63]. Such results reflect the fact that the influence of ghrelin on bone turnover is not dependent on GHS-R1a. Furthermore, in more recent studies, ghrelin has been observed to regulate osteoclastogenesis and bone metabolism in an agebased manner by interacting with leptin [6, 33].

Mouse models of Parkinson's disease and focal ischaemia/reperfusion have indicated that ghrelin-regulated GHS-R1a signals demonstrated protective effects. The neurological disorder of Parkinson's disease manifests clinically as recurrent tremor, rigidity, and bradykinesia. A recent study on C57BL/6 mice found that GHS-R1a signalling dopaminergic neurons for triggering 1-methyl-4-phenyl-1,2,3,6-tetrahydropyridine (MPTP) neurotoxicity were controlled by ghrelin [31].
Ghrelin signals with GHS-R1a mediation could potentially participate in adult hippocampal neurogenesis as progenitor cells have been found to contain hippocampal GHS-R1a. The results of a recent study on adult mice pointed to the fact that hippocampal neuronal progenitor cells activated and differentiated in the sub-granular zone [64]. One study even proposed that GHS-R1 a signalling could be the basis for a strategy for improving dysfunctional learning and memory, since it contributes significantly to the proliferation of adult hippocampal progenitor cells and the early differentiation of neurons, which in turn underpin the generation of agonists in ghrelin receptors [13].

Ghrelin and its receptor have been detected in both rat and human testes $[35,103,104]$, as well as in the organs involved in the human female reproductive system, namely, the ovary, hilum, and corporal lutea [28]. Furthermore, by diminishing the differentiation of hypothalamic gonadotropin release hormone and increasing hormone luteinisation and production of follicle-stimulating hormones, ghrelin contributes significantly to the regulation of the hypothalamic-pituitary-gonadal axis [3].

Another key function attributed to ghrelin is the control of lipid storage by white adipose tissue. GH production is frequently stimulated by extensive ex- 
posure to ghrelin, leading to an expansion in the fat mass. Ghrelin has additionally been observed to improve adipogenesis, enzyme action for fat storage, and the levels of triglycerides, whilst decreasing fat usage and lipolysis [10].

Soon after ghrelin was first identified, one study employed in situ hybridisation and immunocytochemistry to determine whether ghrelin could be expressed in the human pancreas [51]. Findings suggested that ghrelin had an effect on insulin production, being capable of suppressing this production in both humans and rodents, and $\beta$ cells mediated the action of ghrelin [51].

The presence of immunoreactive ghrelin cells throughout the human pancreas has been confirmed via immunostaining. More specifically, the $\alpha, \beta$, and $\delta$ cells in pancreatic islets have been found to have endogenous expression of ghrelin, whilst the $\alpha$ and $\beta$ cells are the main types of pancreatic cells with GSH-R1a expression [60, 99]. Furthermore, the foetal and neonatal pancreas seems to have a considerably higher number of ghrelin cells than the adult pancreas. Moreover, evidence has been produced that immunoreactive ghrelin cells are never associated with hormone in the common $\alpha, \beta, \delta$, and PP-cells in pancreatic islets, as indicated by double or triple immunostaining for ghrelin and the four major islet hormones, namely, glucagon, insulin, somatostatin, and PP-cells [40]. Ghrelin cells have been confirmed to contribute to foetal and neonatal cellular development in rat pancreas $[25,67,101]$, whilst also occurring in mouse pancreas [16].

Ghrelin immunoreactivity has also been reported in Langerhans cell islets, as well as in human $\beta$ cells and human $\alpha$ cells [18].

Furthermore, from day 8 of mouse embryonic development, ghrelin cells start to participate in the formation of Langerhans islets. The pancreas secretes ghrelin on a constant basis during embryonic development, but the release rate decreases rapidly after birth. In humans, only a particular group of cells has ghrelin expression in islets; by contrast, in mice, a subset of $\varepsilon$-cells is chiefly responsible for the glucagon-based production of ghrelin in islets.

GHS-R has been reported to be extensively distributed within the lymphoid system, leading to the suggestion that ghrelin and GHS-R ligands could be potential signal modulators within the immune and endocrine systems, as well as between the central and peripheral nervous systems. Furthermore, human urogenital organs could possibly include nerve-im- mune activity, as deduced from rat model research on ghrelin-positive mast cells in autonomic nerves [72].

\section{CONCLUSIONS}

The stomach is the main source of ghrelin. In terms of cellular types, the stomach and other areas of the GIT contain different forms of ghrelin cells, with both open-type and closed-type of ghrelin cells being present in the stomach and large and small intestines. The ghrelin cells in the stomach are considered to contribute the largest amount of ghrelin in the plasma, whereas the large and small intestines contribute a smaller amount. Further research is necessary in order to shed more light on the biological and histopathological properties of the ghrelin cells present in the large and small intestines.

\section{REFERENCES}

1. Akamizu T, Shinomiya T, Irako T, et al. Separate measurement of plasma levels of acylated and desacyl ghrelin in healthy subjects using a new direct ELISA assay. J Clin Endocrinol Metab. 2005; 90(1): 6-9, doi: 10.1210/jc.2004-1640, indexed in Pubmed: 15483072.

2. Akl A. Review Article. SciFed J Immunol. 2017; 1(1), doi: 10.23959/sfji-1000003.

3. Alkonyi B, Govindan RM, Chugani HT, et al. Focal white matter abnormalities related to neurocognitive dysfunction: an objective diffusion tensor imaging study of children with Sturge-Weber syndrome. Pediatr Res. 2011; 69(1): 74-79, doi: 10.1203/PDR.0b013e3181fcb285, indexed in Pubmed: 20856167.

4. Ariyasu H, Takaya K, Tagami T, et al. Stomach is a major source of circulating ghrelin, and feeding state determines plasma ghrelin-like immunoreactivity levels in humans. J Clin Endocrinol Metab. 2001; 86(10): 4753-4758, doi: 10.1210/ jcem.86.10.7885, indexed in Pubmed: 11600536.

5. Barnett BP, Hwang Y, Taylor MS, et al. Glucose and weight control in mice with a designed ghrelin O-acyltransferase inhibitor. Science. 2010; 330(6011): 1689-1692, doi: 10.1126/ science.1196154, indexed in Pubmed: 21097901.

6. Barreiro ML, Gaytán F, Caminos JE, et al. Cellular location and hormonal regulation of ghrelin expression in rat testis. Biol Reprod. 2002; 67(6): 1768-1776, doi: 10.1095/biolreprod.102.006965, indexed in Pubmed: 12444052.

7. Bonior J, Ceranowicz P, Gajdosz R, et al. Molecular ghrelin system in the pancreatic acinar cells: the role of the polypeptide, caerulein and sensory nerves. Int J Mol Sci. 2017; 18(5), doi: 10.3390/ijms18050929, indexed in Pubmed: 28468316.

8. Bowers CY, Momany F, Reynolds GA, et al. Structure-activity relationships of a synthetic pentapeptide that specifically releases growth hormone in vitro. Endocrinology. 1980; 106(3): 663-667.

9. Caesar DD, Shakkarpude J, Shehar R, et al. Role of hunger hormone: ghrelin. Int J Sci Nat. 2016; 7(1): 6-15.

10. Cao Y, Tang J, Yang T, et al. Cardioprotective effect of ghrelin in cardiopulmonary bypass involves a reduction in inflammatory response. PLoS One. 2013; 8(1): e550211, doi: 10.1371/ journal.pone.0055021, indexed in Pubmed: 23359315.

11. Choe YH, Song SY, Paik KH, et al. Increased density of ghrelin-expressing cells in the gastric fundus and body in Prader-Willi syndrome. J Clin Endocrinol Metab. 2005; 90(9): 5441-5445, doi: 10.1210/jc.2004-1935, indexed in Pubmed: 15956087.

12. Churm R, Davies JS, Stephens JW, et al. Ghrelin function in human obesity and type 2 diabetes: a concise review. Obes 
Rev. 2017; 18(2): 140-148, doi: 10.1111/obr.12474, indexed in Pubmed: 27899023.

13. Cong W, Golden E, Pantaleo N, et al. Ghrelin receptor signaling: a promising therapeutic target for metabolic syndrome and cognitive dysfunction. CNS Neurol Disord Drug Targets. 2010; 9(5): 557-563, doi: 10.2174/187152710793361513, indexed in Pubmed: 20632971.

14. Costa JL, Naot D, Lin JM, et al. Ghrelin is an osteoblast mitogen and increases osteoclastic bone resorption in vitro. Int J Pept. 2011; 2011: 605193, doi: 10.1155/2011/605193, indexed in Pubmed: 21912562.

15. Cummings DE, Purnell JQ, Frayo RS, et al. A preprandial rise in plasma ghrelin levels suggests a role in meal initiation in humans. Diabetes. 2001; 50(8): 1714-1719, doi: 10.2337/ diabetes.50.8.1714, indexed in Pubmed: 11473029.

16. Dantzer R. Cytokine-induced sickness behavior: mechanisms and implications. Ann N Y Acad Sci. 2001; 933: 222-234, doi: 10.1111/j.1749-6632.2001.tb05827.x, indexed in Pubmed: 12000023.

17. da Silva Pereira JA, da Silva FC, de Moraes-Vieira PM. The impact of ghrelin in metabolic diseases: an immune perspective. J Diabetes Res. 2017; 2017: 4527980, doi: 10.1155/2017/4527980, indexed in Pubmed: 29082258.

18. Date $Y$, Nakazato $M$, Hashiguchi $S$, et al. Ghrelin is present in pancreatic: cells of humans and rats and stimulates insulin secretion. Diabetes. 2002; 51(1): 124-129, doi: 10.2337/ diabetes.51.1.124

19. de la Cour CD, Björkqvist $M$, Sandvik AK, et al. A-like cells in the rat stomach contain ghrelin and do not operate under gastrin control. Regul Pept. 2001; 99(2-3): 141-150, doi: 10.1016/ s0167-0115(01)00243-9, indexed in Pubmed: 11384775.

20. de la Cour CD, Lindqvist $A$, Egecioglu $E$, et al. Ghrelin treatment reverses the reduction in weight gain and body fat in gastrectomised mice. Gut. 2005; 54(7): 907-913, doi: 10.1136/gut.2004.058578, indexed in Pubmed: 15849166.

21. de Novaes Rocha N, de Oliveira MV, Braga C, et al. Ghrelin therapy improves lung and cardiovascular function in experimental emphysema. Resp Res. 2017; 18(1): 185, doi: 10.1186/s12931-017-0668-9.

22. de Vriese C, Gregoire F, Lema-Kisoka R, et al. Ghrelin degradation by serum and tissue homogenates: identification of the cleavage sites. Endocrinology. 2004; 145(11): 4997-5005, doi: 10.1210/en.2004-0569, indexed in Pubmed: 15256494.

23. Delporte C. Structure and physiological actions of ghrelin. Scientifica (Cairo). 2013; 2013: 518909, doi: 10.1155/2013/518909, indexed in Pubmed: 24381790.

24. Dezaki K, Sone H, Yada T. Ghrelin is a physiological regulator of insulin release in pancreatic islets and glucose homeostasis. Pharmacol Ther. 2008; 118(2): 239-249, doi: 10.1016/j. pharmthera.2008.02.008, indexed in Pubmed: 18433874.

25. Dixit V, Schaffer E, Pyle R, et al. Ghrelin inhibits leptin- and activation-induced proinflammatory cytokine expression by human monocytes and T cells. J Clin Investigation. 2004; 114(1): 57-66, doi: 10.1172/jci200421134.

26. El-Salhy M, Gilja OH, Gundersen D, et al. Endocrine cells in the oxyntic mucosa of the stomach in patients with irritable bowel syndrome. World J Gastrointest Endosc. 2014; 6(5): 176-185, doi: 10.4253/wjge.v6.i5.176, indexed in Pubmed: 24891930.

27. Esener OBB, Gurel-Gurevin E, Isbilen-Basok B, et al. Spirulina platensis affects factors involved in spermatogenesis and increases ghrelin receptors in testis tissue of rats fed a highfat diet. Pol J Vet Sci. 2017; 20(3): 467-475, doi: 10.1515/ pjvs-2017-0056, indexed in Pubmed: 29166288.

28. Fåk F, Friis-Hansen L, Weström B, et al. Gastric ghrelin cell development is hampered and plasma ghrelin is reduced by delayed weaning in rats. J Endocrinol. 2007; 192(2): 345-352, doi: 10.1677/joe.1.07077, indexed in Pubmed: 17283234.

29. Fujino K, Inui A, Asakawa A, et al. Ghrelin induces fasted motor activity of the gastrointestinal tract in conscious fed rats. J Physiol. 2003; 550(Pt 1): 227-240, doi: 10.1113/jphysiol.2003.040600, indexed in Pubmed: 12837928.
30. Garin MC, Burns CM, Kaul S, et al. Clinical review: the human experience with ghrelin administration. J Clin Endocrinol Metab. 2013; 98(5): 1826-1837, doi: 10.1210/jc.2012-4247, indexed in Pubmed: 23533240.

31. Gaytan F, Barreiro ML, Caminos JE, et al. Expression of ghrelin and its functional receptor, the type 1a growth hormone secretagogue receptor, in normal human testis and testicular tumors. J Clin Endocrinol Metab. 2004; 89(1): 400-409, doi: 10.1210/jc.2003-031375, indexed in Pubmed: 14715878.

32. Ge X, Yang H, Bednarek MA, et al. LEAP2 is an endogenous antagonist of the ghrelin receptor. Cell Metab. 2018; 27(2): 461-469.e6, doi: 10.1016/j.cmet.2017.10.016, indexed in Pubmed: 29233536.

33. Gnanapavan S, Kola B, Bustin SA, et al. The tissue distribution of the mRNA of ghrelin and subtypes of its receptor, GHS-R, in humans. J Clin Endocrinol Metab. 2002; 87(6): 2988-2991, doi: 10.1210/jcem.87.6.8739, indexed in Pubmed: 12050285.

34. Grönberg M, Tsolakis AV, Magnusson L, et al. Distribution of obestatin and ghrelin in human tissues: immunoreactive cells in the gastrointestinal tract, pancreas, and mammary glands. J Histochem Cytochem. 2008; 56(9): 793-801, doi: 10.1369/jhc.2008.951145, indexed in Pubmed: 18474938.

35. Gross L. Review Article. Am J Int Law. 1986; 80(1): 200-215.

36. Gualillo O, Caminos JE, Kojima M, et al. Gender and gonadal influences on ghrelin mRNA levels in rat stomach. Eur J Endocrinol. 2001 ; 144(6): 687-690, doi: 10.1530/eje.0.1440687, indexed in Pubmed: 11375804.

37. Gutierrez JA, Solenberg PJ, Perkins DR, et al. Ghrelin octanoylation mediated by an orphan lipid transferase. Proc Natl Acad Sci U S A. 2008; 105(17): 6320-6325, doi: 10.1073/ pnas.0800708105, indexed in Pubmed: 18443287.

38. Hass N, Schwarzenbacher K, Breer H. T1R3 is expressed in brush cells and ghrelin-producing cells of murine stomach. Cell Tissue Res. 2010; 339(3): 493-504, doi: 10.1007/s00441009-0907-6, indexed in Pubmed: 20063013.

39. Hayashida T, Murakami K, Mogi K, et al. Ghrelin in domestic animals: distribution in stomach and its possible role. Domest Anim Endocrinol. 2001; 21(1): 17-24, doi: 10.1016/ s0739-7240(01)00104-7, indexed in Pubmed: 11524171.

40. Heller RS, Jenny M, Collombat $P$, et al. Genetic determinants of pancreatic epsilon-cell development. Dev Biol. 2005; 286(1): 217-224, doi: 10.1016/j.ydbio.2005.06.041, indexed in Pubmed: 16122727.

41. Hopkins AL, Nelson TAS, Guschina IA, et al. Unacylated ghrelin promotes adipogenesis in rodent bone marrow via ghrelin O-acyl transferase and GHS-R activity: evidence for target cell-induced acylation. Sci Rep. 2017; 7: 45541, doi: 10.1038/srep45541, indexed in Pubmed: 28361877.

42. Hosoda H, Doi K, Nagaya N, et al. Optimum collection and storage conditions for ghrelin measurements: octanoyl modification of ghrelin is rapidly hydrolyzed to desacyl ghrelin in blood samples. Clin Chem. 2004; 50(6): 1077-1080, doi: 10.1373/clinchem.2003.025841, indexed in Pubmed: 15161728.

43. Hosoda H, Kojima M, Mizushima T, et al. Structural divergence of human ghrelin. Identification of multiple ghrelin-derived molecules produced by post-translational processing. J Biol Chem. 2003; 278(1): 64-70, doi: 10.1074/ jbc.M205366200, indexed in Pubmed: 12414809.

44. Howard AD, Feighner SD, Cully DF, et al. A receptor in pituitary and hypothalamus that functions in growth hormone release. Science. 1996; 273(5277): 974-977, doi: 10.1126/ science. 273.5277 .974

45. Howick K, Griffin BT, Cryan JF, et al. From belly to brain: targeting the ghrelin receptor in appetite and food intake regulation. Int J Mol Sci. 2017; 18(2), doi: 10.3390/ ijms18020273, indexed in Pubmed: 28134808.

46. Jiang H, Li L, Wang J, et al. Ghrelin antagonizes MPTP-induced neurotoxicity to the dopaminergic neurons in mouse substantia nigra. Exp Neurol. 2008; 212(2): 532-537, doi: 10.1016/j.expneurol.2008.05.006, indexed in Pubmed: 18577498. 
47. Kaiya H, Kojima M, Hosoda H, et al. aiya H.Peptide purification, complementary deoxyribonucleic acid (DNA) and genomic DNA cloning, and functional characterization of ghrelin in rainbow trout. Endocrinology. 2003; 144(12): 5215-5226, doi: 10.1210/en.2003-1085, indexed in Pubmed: 12970156.

48. Kaiya H, Van der Geyten S, Kojima M, et al. Chicken ghrelin: purification, cDNA cloning, and biological activity. Endocrinology. 2002; 143(9): 3454-3463, doi: 10.1210/en.2002220255, indexed in Pubmed: 12193558.

49. Kojima M, Hosoda H, Date $Y$, et al. Ghrelin is a growth-hormone-releasing acylated peptide from stomach. Nature. 1999; 402(6762): 656-660, doi: 10.1038/45230, indexed in Pubmed: 10604470.

50. Kojima M, Kangawa K. Structure and function of ghrelin. Results Probl Cell Differ. 2008; 46: 89-115, doi: 10.1007/400 2007 049, indexed in Pubmed: 18193177.

51. Kreft $\mathrm{H}$, Jetz $\overline{\mathrm{W}}$. Global patterns and determinants of vascular plant diversity. Proc Natl Acad Sci USA. 2007; 104(14): 5925-5930, doi: 10.1073/pnas.0608361104, indexed in Pubmed: 17379667.

52. Lee HM, Wang G, Englander EW. Ghrelin, a new gastrointestinal endocrine peptide that stimulates insulin secretion: enteric distribution, ontogeny, influence of endocrine, and dietary manipulations. Endocrinology. 2002; 143(1): 185-190.

53. Li B, Lin Q, Guo H, et al. Ghrelin regulates sepsisinduced rat acute gastric injury. Mol Med Rep. 2019; 19(6): 5424-5432, doi: 10.3892/mmr.2019.10208, indexed in Pubmed: 31059095.

54. Lo Cascio P, Calabrò C, Bertuccio C, et al. Immunohistochemical characterization of Pept 1 and ghrelin in gastrointestinal tract of zebrafish: effects of vegetarian diet on the neuroendocrine system cells after alimentary stress. Front Physiol. 2018; 9: 614, doi: 10.3389/fphys.2018.00614, indexed in Pubmed: 29881359.

55. Longo KA, Charoenthongtrakul S, Giuliana DJ, et al. Improved insulin sensitivity and metabolic flexibility in ghrelin receptor knockout mice. Regul Pept. 2008; 150(1-3): 55-61, doi: 10.1016/j.regpep.2008.03.011, indexed in Pubmed: 18453014.

56. Lv Y, Liang T, Wang G, et al. Ghrelin, a gastrointestinal hormone, regulates energy balance and lipid metabolism. Biosci Rep. 2018; 38(5), doi: 10.1042/BSR20181061, indexed in Pubmed: 30177523.

57. Mani BK, Walker AK, Lopez Soto EJ, et al. Neuroanatomical characterization of a growth hormone secretagogue receptor-green fluorescent protein reporter mouse. J Comp Neurol. 2014; 522(16): 3644-3666, doi: 10.1002/cne.23627, indexed in Pubmed: 24825838.

58. Matsubara M, Sakata I, Wada R. Estrogen modulates ghrelin expression in the female rat stomach. Peptides. 2004; 25(2): 289-297, doi: 10.1016/j.peptides.2003.12.020, indexed in Pubmed: 15063011.

59. McFarlane MR, Brown MS, Goldstein JL, et al. Induced ablation of ghrelin cells in adult mice does not decrease food intake, body weight, or response to high-fat diet. Cell Metab. 2014; 20(1): 54-60, doi: 10.1016/j.cmet.2014.04.007, indexed in Pubmed: 24836560.

60. McLarnon A. Metabolism: age-dependent balance of leptin and ghrelin regulates bone metabolism. Nat Rev Endocrinol. 2012; 8(9): 504, doi: 10.1038/nrendo.2012.116, indexed in Pubmed: 22751345.

61. Mihalache L, Arhire LI, Giuşcă SE, et al. Ghrelin-producing cells distribution in the stomach and the relation with Helicobacter pylori in obese patients. Rom J Morphol Embryol. 2019; 60(1): 219-225, indexed in Pubmed: 31263848.

62. Momany FA, Bowers CY, Reynolds GA, et al. Design, synthesis, and biological activity of peptides which release growth hormone in vitro. Endocrinology. 1981; 108(1): 31-39, doi: 10.1210/endo-108-1-31, indexed in Pubmed: 6109621.

63. Moon M, Kim S, Hwang L, et al. Ghrelin regulates hippocampal neurogenesis in adult mice. Endocr J. 2009; 56(3): 525-531, doi: 10.1507/endocrj.k09e-089, indexed in Pubmed: 19506321
64. Muccioli G, Lorenzi T, Lorenzi M, et al. Beyond the metabolic role of ghrelin: a new player in the regulation of reproductive function. Peptides. 2011; 32(12): 2514-2521, doi: 10.1016/j. peptides.2011.10.020, indexed in Pubmed: 22074955.

65. Müller TD, Nogueiras R, Andermann ML, et al. Ghrelin. Mol Metab. 2015; 4(6): 437-460, doi: 10.1016/j.molmet.2015.03.005, indexed in Pubmed: 26042199.

66. Nakazato M, Murakami N, Date Y, et al. A role for ghrelin in the central regulation of feeding. Nature. 2001; 499(6817): 194198, doi: 10.1038/35051587, indexed in Pubmed: 11196643.

67. Napolitano T, Silvano S, Vieira A, et al. Role of ghrelin in pancreatic development and function. Diabetes Obes Metab. 2018; 20 Suppl 2: 3-10, doi: 10.1111/dom.13385, indexed in Pubmed: 30230184.

68. Nass R, Gaylinn BD, Thorner MO. The ghrelin axis in disease: potential therapeutic indications. Mol Cell Endocrinol. 2011; 340(1): 106-110, doi: 10.1016/j.mce.2011.02.010, indexed in Pubmed: 21356273.

69. Pagotto U, Gambineri A, Pelusi C, et al. Testosterone replacement therapy restores normal ghrelin in hypogonadal men. J Clin Endocrinol Metab. 2003; 88(9): 4139-4143, doi: 10.1210/jc.2003-030554, indexed in Pubmed: 12970277.

70. Patterson M, Murphy KG, le Roux CW, et al. Characterization of ghrelin-like immunoreactivity in human plasma. J Clin Endocrinol Metab. 2005; 90(4): 2205-2211, doi: 10.1210/ jc.2004-1641, indexed in Pubmed: 15657369.

71. Pemberton $C$, Wimalasena $P$, Yandle $T$, et al. C-terminal pro-ghrelin peptides are present in the human circulation. Biochem Biophys Res Commun. 2003; 310(2): 567-573, doi: 10.1016/j.bbrc.2003.09.045, indexed in Pubmed: 14521948.

72. Perez-Tilve D, Heppner K, Kirchner H, et al. Ghrelin-induced adiposity is independent of orexigenic effects. FASEB J. 2011; 25(8): 2814-2822, doi: 10.1096/fj.11-183632, indexed in Pubmed: 21543764.

73. Popovic V, Miljic D, Pekic S, et al. Low plasma ghrelin level in gastrectomized patients is accompanied by enhanced sensitivity to the ghrelin-induced growth hormone release. J Clin Endocrinol Metab. 2005; 90(4): 2187-2191, doi: 10.1210/ jc. 2004-1888, indexed in Pubmed: 15644398.

74. Pradhan G, Samson S, Sun Y. Ghrelin: much more than a hunger hormone. Curr Opin Clin Nutr Metab Care. 2013; 16(6): 619-624, doi: 10.1097/mco.0b013e328365b9be.

75. Rindi G, Savio A, Torsello A, et al. Ghrelin expression in gut endocrine growths. Histochem Cell Biol. 2002; 117(6): 521-525, doi: 10.1007/s00418-002-0416-0, indexed in Pubmed: 12107502

76. Sakata I, Mori T, Kaiya H, et al. Localization of ghrelin-producing cells in the stomach of the rainbow trout (Oncorhynchus mykiss). Zoolog Sci. 2004; 21(7): 757-762, doi: 10.2108/ zsj.21.757, indexed in Pubmed: 15277719.

77. Sakata I, Nakamura K, Yamazaki M, et al. Ghrelin-producing cells exist as two types of cells, closed- and opened-type cells, in the rat gastrointestinal tract. Peptides. 2002; 23(3): 531-536, doi: 10.1016/s0196-9781(01)00633-7, indexed in Pubmed: 11836003.

78. Sakata I, Nakano Y, Osborne-Lawrence S, et al. Characterization of a novel ghrelin cell reporter mouse. Regul Pept. 2009; 155(1-3): 91-98, doi: 10.1016/j.regpep.2009.04.001, indexed in Pubmed: 19361544

79. Sakata I, Sakai T. Ghrelin cells in the gastrointestinal tract. Int J Pept. 2010; 2010, doi: 10.1155/2010/945056, indexed in Pubmed: 20798855.

80. Sakata I, Tanaka T, Matsubara M, et al. Postnatal changes in ghrelin mRNA expression and in ghrelin-producing cells in the rat stomach. J Endocrinol. 2002; 174(3): 463-471, doi: 10.1677/joe.0.1740463, indexed in Pubmed: 12208667.

81. Sangiao-Alvarellos S, Cordido F. Effect of ghrelin on glucose-insulin homeostasis: therapeutic implications. Int J Pept. 2010; 2010, doi: 10.1155/2010/234709, indexed in Pubmed: 20700401.

82. Sato T, Nakamura Y, Shiimura $Y$, et al. Structure, regulation and function of ghrelin. J Biochem. 2012; 151(2): 119-128, doi: 10.1093/jb/mvr134, indexed in Pubmed: 22041973. 
83. Shah M, Kola B, Batavejic A, et al. AMP-activated protein kinase (AMPK) activation regulates in vitro bone formation and bone mass. Bone. 2010; 47(2): 309-319, doi: 10.1016/j. bone.2010.04.596, indexed in Pubmed: 20399918.

84. Shanado Y, Kometani M, Uchiyama H, et al. Lysophospholipase I identified as a ghrelin deacylation enzyme in rat stomach. Biochem Biophys Res Commun. 2004; 325(4): 1487-1494, doi: 10.1016/j.bbrc.2004.10.193, indexed in Pubmed: 15555596.

85. Smith RG, Van der Ploeg LH, Howard AD, et al. Peptidomimetic regulation of growth hormone secretion. Endocr Rev. 1997; 18(5): 621-645, doi: 10.1210/edrv.18.5.0316, indexed in Pubmed: 9331545.

86. Soleyman-Jahi S, Sadeghi F, Pastaki Khoshbin A, et al. Attribution of ghrelin to cancer; attempts to unravel an apparent controversy. Front Oncol. 2019; 9: 1014, doi: 10.3389/ fonc.2019.01014, indexed in Pubmed: 31681567.

87. Stefanov I, Ananiev J, Ivanova K, et al. Distribution of ghrelin-positive mast cells in rat stomach. Biotechnol Biotechnol Equip. 2017: 1-8, doi: 10.1080/13102818.2017.1326013.

88. Steinert RE, Feinle-Bisset C, Asarian L, et al. Ghrelin, CCK, GLP-1, and PYY(3-36): secretory controls and physiological roles in eating and glycemia in health, obesity, and after RYGB. Physiol Rev. 2017; 97(1): 411-463, doi: 10.1152/ physrev.00031.2014, indexed in Pubmed: 28003328.

89. Suda Y, Kuzumaki N, Sone T, et al. Down-regulation of ghrelin receptors on dopaminergic neurons in the substantia nigra contributes to Parkinson's disease-like motor dysfunction. Mol Brain. 2018; 11(1): 6, doi: 10.1186/s13041-018-0349-8, indexed in Pubmed: 29458391.

90. Sun Y, Ahmed S, Smith RG. Deletion of ghrelin impairs neither growth nor appetite. Mol Cell Biol. 2003; 23(22): 7973-7981, doi: $10.1128 / \mathrm{mcb} .23 .22 .7973-7981.2003$, indexed in Pubmed: 14585959.

91. Sun Y, Asnicar M, Saha PK, et al. Ablation of ghrelin improves the diabetic but not obese phenotype of ob/ob mice. Cell Metab. 2006; 3(5): 379-386, doi: 10.1016/j.cmet.2006.04.004, indexed in Pubmed: 16679295.

92. Sun $Y$, Wang $P$, Zheng $H$, et al. Ghrelin stimulation of growth hormone release and appetite is mediated through the growth hormone secretagogue receptor. Proc Natl Acad Sci U S A. 2004; 101(13): 4679-4684, doi: 10.1073/ pnas.0305930101, indexed in Pubmed: 15070777.

93. Tanaka-Shintani M, Watanabe M. Distribution of ghrelin-immunoreactive cells in human gastric mucosa: comparison with that of parietal cells. J Gastroenterol. 2005; 40(4): 345-349, doi: 10.1007/s00535-004-1550-3, indexed in Pubmed: 15870970

94. Teive MB, Russi RF, Vieira DS, et al. Quantitative immunohistochemical analysis of duodenal ghrelin cells after sleeve gastrectomy in Wistar rats. Acta Cir Bras. 2012; 27(9): 595-599, doi: 10.1590/s0102-86502012000900001, indexed in Pubmed: 22936082.

95. Tomasetto C, Karam SM, Ribieras S, et al. Identification and characterization of a novel gastric peptide hormone: the motilin-related peptide. Gastroenterology. 2000; 119(2): 395-405, doi: 10.1053/gast.2000.9371, indexed in Pubmed: 10930375.

96. Tschöp M, Flora DB, Mayer JP, et al. Hypophysectomy prevents ghrelin-induced adiposity and increases gastric ghrelin secretion in rats. Obes Res. 2002; 10(10): 991-999, doi: 10.1038/oby.2002.135, indexed in Pubmed: 12376579.

97. Tschöp M, Smiley DL, Heiman ML. Ghrelin induces adiposity in rodents. Nature. 2000; 407(6806): 908-913, doi: 10.1038/35038090, indexed in Pubmed: 11057670.

98. van der Lely AJ, Tschöp M, Heiman ML, et al. Biological, physiological, pathophysiological, and pharmacological aspects of ghrelin. Endocr Rev. 2004; 25(3): 426-457, doi: 10.1210/ er.2002-0029, indexed in Pubmed: 15180951.

99. Van Der Velde $M$, Van Der Eerden $B C$, Sun $Y$, et al. An age-dependent interaction with leptin unmasks ghrelin's bone-protective effects. Endocrinology. 2012; 153(8):
3593-3602, doi: 10.1210/en.2012-1277, indexed in Pubmed: 22700774.

100. Vitari F, Di Giancamillo A, Deponti D, et al. Distribution of ghrelin-producing cells in the gastrointestinal tract of pigs at different ages. Vet Res Commun. 2012; 36(1): 71-80, doi: 10.1007/s11259-012-9517-y, indexed in Pubmed: 22281862.

101. Volante $M$, Allia E, Gugliotta $P$, et al. Expression of ghrelin and of the $\mathrm{GH}$ secretagogue receptor by pancreatic islet cells and related endocrine tumors. J Clin Endocrinol Metab. 2002; 87(3): 1300-1308, doi: 10.1210/jcem.87.3.8279, indexed in Pubmed: 11889202.

102. Walia P, Asadi A, Kieffer TJ, et al. Ontogeny of ghrelin, obestatin, preproghrelin, and prohormone convertases in rat pancreas and stomach. Pediatr Res. 2009; 65(1): 39-44, doi: 10.1203/PDR.0b013e31818bc134, indexed in Pubmed: 18784614.

103. Wierup N, Sundler F. Human and murine pancreatic ghrelin cells. Developmental aspects and ultrastructure. Regulatory Peptides. 2004; 122(1): 48.

104. Wierup N, Sundler F. Neuropeptides: endocrine cells. Encyclopedia of Neuroscience. 2009: 891-897, doi: 10.1016/ b978-008045046-9.01457-1.

105. Wierup N, Sundler F, Scott Heller R. The islet ghrelin cell. J Mol Endocrinol. 2014; 52(1): R35-R49, doi: 10.1530/ jme-13-0122.

106. Wortley KE, Anderson KD, Garcia K, et al. Genetic deletion of ghrelin does not decrease food intake but influences metabolic fuel preference. Proc Natl Acad Sci U S A. 2004; 101(21): 8227-8232, doi: 10.1073/pnas.0402763101, indexed in Pubmed: 15148384.

107. Wortley KE, del Rincon JP, Murray JD, et al. Absence of ghrelin protects against early-onset obesity. J Clin Invest. 2005; 115(12): 3573-3578, doi: 10.1172/JCI26003, indexed in Pubmed: 16322795.

108. Yabuki A, Ojima T, Kojima M, et al. Characterization and species differences in gastric ghrelin cells from mice, rats and hamsters. J Anat. 2004; 205(3): 239-246, doi: 10.1111/j.00218782.2004.00331.x, indexed in Pubmed: 15379929.

109. Yang J, Brown MS, Liang G, et al. Goldstein, Identification of the acyltransferase that octanoylates ghrelin, an appetite-stimulating peptide hormone. Cell. 2008; 132(3): 387-396, doi: 10.1016/j.cell.2008.01.017, indexed in Pubmed: 18267071.

110. Yoshihara F, Kojima M, Hosoda H, et al. Ghrelin: a novel peptide for growth hormone release and feeding regulation. Curr Opin Clin Nutr Metab Care. 2002; 5(4): 391-395, doi: 10.1097/00075197-200207000-00007, indexed in Pubmed: 12107374.

111. Zhang G, Yin X, Qi Y, et al. Ghrelin and cardiovascular diseases. Curr Cardiol Rev. 2010; 6(1): 62-70, doi: 10.2174/157340310790231662, indexed in Pubmed: 21286280 .

112. Zhao CM, Furnes MW, Stenström B, et al. Characterization of obestatin- and ghrelin-producing cells in the gastrointestinal tract and pancreas of rats: an immunohistochemical and electron-microscopic study. Cell Tissue Res. 2008; 331(3): 575-587, doi: 10.1007/s00441-007-0514-3, indexed in Pubmed: 18071756.

113. Zhao TJ, Liang G, Li RL, et al. Ghrelin O-acyltransferase (GOAT) is essential for growth hormone-mediated survival of calorie-restricted mice. Proc Natl Acad Sci. 2010; 107(16): 7467-7472, doi: 10.1073/pnas.1002271107.

114. Zhao Z, Sakai T. Characteristic features of ghrelin cells in the gastrointestinal tract and the regulation of stomach ghrelin expression and production. World J Gastroenterol. 2008; 14(41): 6306-6311, doi: 10.3748/wjg.14.6306, indexed in Pubmed: 19009644.

115. Zigman JM, Nakano Y, Coppari R, et al. Mice lacking ghrelin receptors resist the development of diet-induced obesity. J Clin Invest. 2005; 115(12): 3564-3572, doi: 10.1172/ $\mathrm{JCl} 26002$, indexed in Pubmed: 16322794. 